\title{
Taxonomic Study of Bacteria Isolated from Plants: Proposal of Sphingomonas rosa sp. nov., Sphingomonas pruni sp. nov., Sphingomonas asaccharolytica sp. nov., and Sphingomonas mali sp. nov.

\author{
MARIKO TAKEUCHI,${ }^{1 *}$ TAKESHI SAKANE,${ }^{1}$ MIYOKO YANAGI,${ }^{2} \dagger$ KAZUHIDE YAMASATO,${ }^{2} \ddagger$ \\ KOEI HAMANA, ${ }^{3}$ AND AKIRA YOKOTA ${ }^{1} \S$
}

Institute for Fermentation, Osaka, Yodogawa-ku, Osaka 532, ${ }^{1}$ Institute of Applied Microbiology, "The University of Tokyo, Yayoi, Bunkyo-ku, Tokyo $113,{ }^{2}$ and College of Medical Care and Technology, Gunma University, Maebashi-shi, Gunma $371,{ }^{3}$ Japan

\begin{abstract}
The taxonomic positions of 10 strains of 3-ketolactose-forming bacteria which were isolated from the roots of plants (Rosa sp., Psychotria nairobiensis, Ardisia crispa, Prunus persica, and apple trees) were investigated. The DNA base compositions of these strains ranged from 64.0 to $65.7 \mathrm{~mol} \%$, the isoprenoid quinone of each strain was ubiquinone 10,3-hydroxy fatty acids were lacking in the cellular fatty acids of these organisms, and all of the strains contained a sphingolipid with the long-chain base dihydrosphingosin. These are characteristics of the genus Sphingomonas. On the basis of morphological, physiological, and chemotaxonomic characteristics, together with DNA-DNA hybridization and 16S ribosomal DNA sequence comparison data, we propose the following four new species of the genus Sphingomonas: Sphingomonas rosa (type strain, IFO 15208) for the strains isolated from rose plants and formerly named [Agrobacterium rhizogenes]; Sphingomonas pruni (type strain, IFO 15498) for the strains isolated from Prunus persica; and Sphingomonas asaccharolytica (type strain, IFO 15499) and Sphingomonas mali (type strain, IFO 15500) for the strains isolated from apple trees. Two strains which were isolated from Psychotria nairobiensis and formerly named [Chromobacterium lividum] were identified as Sphingomonas yanoikuyae strains.
\end{abstract}

3-Ketolactose-forming activity (2) has been found only in biovar 1 strains of the genus Agrobacterium $(3,10)$, and this characteristic has proven to be a useful taxonomic marker for agrobacteria. Holmes and Roberts (8) proposed an identification scheme for agrobacteria based on 84 phenotypic tests. Fifty Agrobacterium strains, mostly strains maintained in the National Collection of Plant Pathogenic Bacteria, were separated into four clusters on the basis of the results of a numerical analysis. Holmes and Roberts suggested that a small group of "yellow-pigmented, 3-ketolactose positive bacteria," including [Agrobacterium rhizogenes] NCPPB 2661, NCPPB 2662, and NCPPB 2663, which were isolated from hairy roots of Rosa sp., and [Chromobacterium lividum] NCTC 10590 and NCTC 10591, which were isolated from Psychotria nairobiensis or Ardisia crispa, may constitute another distinct group of agrobacteria (brackets indicate taxa that are misnamed). The results of rRNA cistron similarity studies indicated that these strains are more closely related to Flavobacterium capsulatum than to the genus Agrobacterium (1). F. capsulatum was subsequently transferred to the genus Sphingomonas as Sphingomonas capsulata by Yabuuchi et al. in 1990 (27).

The genus Sphingomonas was proposed by Yabuuchi et al.

${ }^{*}$ Corresponding author. Mailing address: Institute for Fermentation, Osaka, 17-85, Juso-honmachi 2-chome, Yodogawa-ku, Osaka 532, Japan. Phone: 81-6-300-6555. Fax: 81-6-300-6814.

$\dagger$ Present address: Abiko Research Laboratory, Central Research Institute of Electric Power Industry, Biotechnology Department, 1646 Abiko, Abiko-shi, Chiba 270-11, Japan.

$\ddagger$ Present address: The Culture Collection Center, Tokyo University of Agriculture, Sakuragaoka, Setagaya-ku, Tokyo 156, Japan.

$\S$ Present address: Institute of Molecular and Cellular Biosciences, The University of Tokyo, Yayoi, Bunkyo-ku, Tokyo 113, Japan.

" Present name: Institute of Molecular and Cellular Biosciences.
(27), and the description of this taxon has recently been emended by us (20). Members of the genus Sphingomonas are yellow-pigmented, nonfermentative, gram-negative, nonmotile or motile rods with a single polar flagellum and are characterized by the presence of a large amount of a unique sphingoglycolipid with the long-chain base dihydrosphingosin, by the presence of 2-hydroxymyristic acid (2-OH 14:0), by the absence of 3-hydroxy fatty acids, and by the presence of ubiquinone 10 (Q-10). Therefore, we examined the taxonomic positions of the five strains of yellow-pigmented 3-ketolactose-positive bacteria described by Holmes and Roberts (8). An additional five strains of 3-ketolactose-positive bacteria, which were isolated from plants and were designated agrobacterium-like strains, were also studied.

In this paper, we report both the phenotypic and chemotaxonomic characteristics of 3-ketolactose-positive bacteria and the results of a comparison of the 16S rRNA gene (rDNA) sequences of these organisms with the sequences of previously described species of the genus Sphingomonas $(20,27)$ and Rhizomonas suberifaciens (23). On the basis of phenotypic data, DNA-DNA hybridization data, and the results of the $16 \mathrm{~S}$ rDNA sequence analysis, we propose four new species of the genus Sphingomonas.

\section{MATERIALS AND METHODS}

Microorganisms and cultures. The strains which we used are listed in Table 1 . The type strains of Sphingomonas species and two strains of Rhizomonas suberifaciens (23) were used for a comparison of taxonomic characteristics. All of the strains except the Rhizomonas suberifaciens strains were cultured at $28^{\circ} \mathrm{C}$ with aerobic shaking in PY medium containing $1 \%$ peptone, $0.2 \%$ yeast extract, $0.2 \%$ $\mathrm{NaCl}$, and $0.2 \%$ glucose $(\mathrm{pH} 7.0)$. Rhizomonas suberifaciens IFO $15211^{\mathrm{T}}(\mathrm{T}=$ type strain) and IFO 15212 were cultured at $28^{\circ} \mathrm{C}$ with aerobic shaking in PG medium containing $0.5 \%$ peptone, $0.25 \%$ glucose, $0.13 \% \mathrm{~K}_{2} \mathrm{HPO}_{4}, 0.05 \%$ $\mathrm{MgSO}_{4} \cdot 7 \mathrm{H}_{2} \mathrm{O}, 0.05 \% \mathrm{KNO}_{3}$, and $0.006 \% \mathrm{Ca}\left(\mathrm{NO}_{3}\right)_{2} \cdot 4 \mathrm{H}_{2} \mathrm{O}(\mathrm{pH} 7.2)$.

Determination of phenotypic characteristics. Cultures were grown on PY or 
TABLE 1. Bacterial strains studied

\begin{tabular}{|c|c|c|c|c|}
\hline Species or isolate & IFO no. ${ }^{a}$ & Other designation(s) ${ }^{b}$ & Source & Reclassified as: \\
\hline [Agrobacterium rhizogenes] & $15208^{\mathrm{T}}$ & NCPPB $2661^{\mathrm{T}}$, IAM $14222^{\mathrm{T}}$ & Rosa $\mathrm{sp}$. roots & Sphingomonas rosa \\
\hline [Agrobacterium rhizogenes] & 15209 & NCPPB 2662 & Rosa sp. roots & Sphingomonas rosa \\
\hline [Agrobacterium rhizogenes] & 15210 & NCPPB 2663 & Rosa sp. roots & Sphingomonas rosa \\
\hline [Chromobacterium lividum] & 15163 & NCTC 10590, IAM 14225 & Psychotria nairobiensis roots & Sphingomonas yanoikuyae \\
\hline [Chromobacterium lividum] & 15164 & NCTC 10591 & Ardisia crispa roots & Sphingomonas yanoikuyae \\
\hline $\mathrm{Y}-250^{\mathrm{T} c}$ & $15498^{\mathrm{T}}$ & & Prunus persica roots & Sphingomonas pruni \\
\hline $\mathrm{Y}-345^{\mathrm{Tc}}$ & $15499^{\mathrm{T}}$ & & Apple tree roots & Sphingomonas asaccharolytica \\
\hline $\mathrm{Y}-347^{\mathrm{T} c}$ & $15500^{\mathrm{T}}$ & & Apple tree roots & Sphingomonas mali \\
\hline $\mathrm{Y}-348^{c}$ & 15501 & & Apple tree roots & Sphingomonas mali \\
\hline $\mathrm{Y}-351^{c}$ & 15502 & & Apple tree roots & Sphingomonas mali \\
\hline Sphingomonas paucimobilis & $13935^{\mathrm{T}}$ & $\mathrm{JCM} 7516^{\mathrm{T}}$ & & \\
\hline Sphingomonas parapaucimobilis & $15100^{\mathrm{T}}$ & $\mathrm{JCM} 7510^{\mathrm{T}}$ & & \\
\hline Sphingomonas yanoikuyae & $15102^{\mathrm{T}}$ & $\mathrm{JCM} 7371^{\mathrm{T}}$ & & \\
\hline Sphingomonas adhaesiva & $15099^{\mathrm{T}}$ & $\mathrm{JCM} 7370^{\mathrm{T}}$ & & \\
\hline Sphingomonas capsulata & $12533^{\mathrm{T}}$ & JCM $7508^{\mathrm{T}}$ & & \\
\hline Sphingomonas sanguis & $13937^{\mathrm{T}}$ & $\mathrm{JCM} 7514^{\mathrm{T}}$ & & \\
\hline Sphingomonas macrogoltabidus & $15033^{\mathrm{T}}$ & & & \\
\hline Sphingomonas terrae & $15098^{\mathrm{T}}$ & $\mathrm{JCM} 7513^{\mathrm{T}}$ & & \\
\hline Rhizomonas suberifaciens & $15211^{\mathrm{T}}$ & & & \\
\hline Rhizomonas suberifaciens & 15212 & & & \\
\hline
\end{tabular}

${ }^{a}$ IFO, Institute for Fermentation, Osaka, Osaka, Japan.

${ }^{b}$ NCPPB, National Collection of Plant Pathogenic Bacteria, Harpenden, England; NCTC, National Collection of Type Cultures, Central Public Health Laboratory, London, England; JCM, Japan Collection of Microorganisms, Institute of Physical and Chemical Research (RIKEN), Hirosawa, Wako, Japan; IAM, Microbial and Microalgal Research Center, Institute of Applied Microbiology, The University of Tokyo, Tokyo, Japan.

${ }^{c}$ Designation of Michio Yasuda, Fruit Tree Research Station, Ministry of Agriculture, Forestry and Fisheries, Tsukuba, Ibaraki, Japan.

PG medium containing 1.5\% agar. API 20NE tests (API, La Balme les Grottes, Montalieu Vercieu, France) were used to determine physiological and biochemical characteristics. API AUX medium containing $0.2 \%$ carbohydrates was used to determine carbohydrate assimilation, and peptone-yeast extract-phenol red medium (26) containing $0.2 \%$ carbohydrates was used to determine acid production. The 3-ketolactose test (formation of 3-ketolactose from lactose) was carried out by the method of Bernaerts and De Ley (3). Quantitative determination of 3-ketolactose was performed by high-performance liquid chromatography (HPLC) (12) as described previously (22). The method used to identify 3-ketolactose from Sphingomonas strains is described in the accompanying paper (15).

Determination of chemotaxonomic characteristics. Analyses to determine cellular fatty acids, sphingolipids, isoprenoid quinones, and $\mathrm{G}+\mathrm{C}$ contents of DNAs and DNA-DNA hybridization experiments were performed as described previously (20). Polyamines were analyzed by HPLC as described previously (6).

$16 S$ rDNA sequence determination and analysis. Wet cells (1 to $3 \mathrm{mg}$ ) were suspended in $300 \mu \mathrm{l}$ of InstaGene purification matrix (Bio-Rad Co., Ltd., Richmond, Calif.), incubated at $56^{\circ} \mathrm{C}$ for 15 to $30 \mathrm{~min}$, sonicated at $100 \mathrm{~W}$ for $30 \mathrm{~s}$, and heated for $5 \mathrm{~min}$. After centrifugation at $1,000 \times \mathrm{g}$ for 2 to $3 \mathrm{~min}$, the supernatant was subjected directly to PCR amplification (7) by using a Taq polymerase kit (Cetus, Inc., Norwalk, Conn.). The purified PCR products of isolates Y-250 ${ }^{\mathrm{T}}\left(=\mathrm{IFO} 15498^{\mathrm{T}}\right), \mathrm{Y}-345^{\mathrm{T}}\left(=\right.$ IFO $\left.15499^{\mathrm{T}}\right)$, and $\mathrm{Y}-347^{\mathrm{T}}(=\mathrm{IFO}$ $15500^{\mathrm{T}}$ ) were sequenced by using a Sequenase kit for ${ }^{35} \mathrm{~S}$-dATP (United Biochemical, Inc., Cleveland, Ohio) (16) and the following four primers: primer $350 \mathrm{R}$, covering the sequence from position 342 to position 357 (Escherichia coli numbering [4]); primer 520R, covering the sequence from position 517 to position 531; primer $920 \mathrm{R}$, covering the sequence from position 907 to position 924; and primer $1400 \mathrm{R}$, covering the sequence from position 1392 to position 1406 The $16 \mathrm{~S}$ rDNA sequences of $[A$. rhizogenes] IFO 15208 (= IAM 14222) and [C. lividum] IFO 15163 (= IAM 14225) were determined with a model 373A automated fluorescent-DNA sequencer (Applied Biosystems Co., Ltd., Foster City, Calif.) and a Dye Primer Cycle sequencing kit, using dye primer-21M13 (Applied Biosystems) as described previously (28). DNA sequences were aligned by using the ODEN system (9). Nucleotide substitution rates ( $K_{\text {nuc }}$ values) were calculated (11), and a phylogenetic tree was constructed by the neighbor-joining method (14). The sequences were aligned with previously published sequences obtained from DNA databases.

Nucleotide sequence accession numbers. The accession numbers of the sequences used for comparison with the sequences which we determined are as follows: Erythrobacter longus, M59062; Roseobacter denitrificans, M96746; Porphyrobacter neustonensis, M96745; Sphingomonas paucimobilis IFO $13935^{\mathrm{T}}$, D13725; Sphingomonas parapaucimobilis IFO $15100^{\mathrm{T}}$, D13724; Sphingomonas adhaesiva, GIFU11458, D16146; Sphingomonas sanguis IFO 13937 ${ }^{\mathrm{T}}$, D13726; $S$. capsulata, M59296; Sphingomonas yanoikuyae IFO 15102' ${ }^{\mathrm{T}}$, D13728; Sphingomonas terrae IFO $15098^{\mathrm{T}}$, D13727; Sphingomonas macrogoltabidus IFO $15033^{\mathrm{T}}$, D13723; and Rhizomonas suberifaciens IFO $15211^{\mathrm{T}}$, D13737. The nucleotide sequence data for new species of the genus Sphingomonas and other sequences which we determined have been deposited in the DNA Data Bank of Japan database under the following accession numbers: Sphingomonas asaccharolytica IFO $15499^{\mathrm{T}}$, D28571, D28572, and D28573; Sphingomonas mali IFO $15500^{\mathrm{T}}$, D28574, D28575, and D28576; Sphingomonas pruni IFO $15498^{\mathrm{T}}$, D28568, D28569, and D28570; Sphingomonas rosa [A. rhizogenes] IFO 15208, D13945; and $S$. yanoikuyae [C. lividum] IFO 15163, D13946.

\section{RESULTS}

Morphological, physiological, and biochemical characteristics. All of the strains which we studied were gram-negative, motile rods. As shown in Table 2, all of the strains gave positive results in tests for 3-ketolactose production, $\beta$-galactosidase activity, esculin hydrolysis, and assimilation of maltose and xylose, and all of the strains gave negative results in tests for arginine dihydrolase activity, urease activity, production of indole, and assimilation of adipate, adonitol, inositol, malonate, mannitol, oxalate, sorbitol, and tartrate. The 10 strains were separated into five groups on the basis of their phenotypic characteristics. The first group consisted of three [A. rhizogenes] strains; the second group consisted of two [C. lividum] strains; the third and fourth groups each contained a single agrobacterium-like isolate $\left(\mathrm{Y}-250^{\mathrm{T}}\left[=\mathrm{IFO} 15498^{\mathrm{T}}\right]\right.$ and $\mathrm{Y}-345^{\mathrm{T}}$ $\left[=\right.$ IFO $\left.\left.15499^{\mathrm{T}}\right]\right)$; and the fifth group consisted of strains $\mathrm{Y}-347^{\mathrm{T}}$ (= IFO $\left.15500^{\mathrm{T}}\right), \mathrm{Y}-348$ (= IFO 15501), and Y-351 (= IFO 15502).

Chemical characteristics. The chemical characteristics of the test strains are summarized in Tables 3 and 4 . All of the strains contained ubiquinone Q-10, and the DNA base compositions ranged from 64.0 to $65.9 \mathrm{~mol} \%$. All of the strains contained sphingolipids, and the long-chain bases in the sphingolipids of [C. lividum] IFO 15163 were identified as dihydrosphingosins (d18:0, d20:1, and d21:1) by gas chromatography-mass spectrometry (data not shown). In the three strains of [A. rhizogenes], octadecenoic acid (18:1) and hexadecenoic acid (16:1) were major nonpolar fatty acids, while in the [C. lividum] strains and the agrobacterium-like isolates, 18:1 fatty acids were the major fatty acids; similarly, small amounts of 16:1 fatty acids were also present, and in agrobacterium-like 
TABLE 2. Physiological characteristics of 3-ketolactose-producing strains

\begin{tabular}{|c|c|c|c|c|c|}
\hline Characteristic & $\begin{array}{c}\text { [A. rhizogenes] } \\
\text { IFO } 15208^{\mathrm{T}} \text {, } \\
\text { IFO } 15209, \\
\text { and IFO } 15210\end{array}$ & $\begin{array}{l}\text { [C. lividum] } \\
\text { IFO } 15163 \text { and } \\
\text { IFO } 15164\end{array}$ & $\begin{array}{l}\text { Strain } \\
\text { Y- } 250^{\mathrm{T}}\end{array}$ & $\begin{array}{l}\text { Strain } \\
\text { Y-345 }\end{array}$ & $\begin{array}{c}\text { Strains } Y-347^{\mathrm{T}} \\
\text { Y-348, and } \\
\text { Y-351 }\end{array}$ \\
\hline 3-Ketolactose production & $t^{a}$ & + & + & + & + \\
\hline$\beta$-Galactosidase & + & + & + & + & + \\
\hline Reduction of nitrate & w & + & - & - & - \\
\hline Deamination of phenylalanine & + & - & - & - & - \\
\hline Arginine dihydrolase & - & - & - & - & - \\
\hline Urease & - & - & - & - & - \\
\hline Liquefaction of gelatin & - & + & - & - & - \\
\hline Hydrolysis of esculin & + & + & + & + & + \\
\hline Production of indole & - & - & - & - & - \\
\hline \multicolumn{6}{|l|}{ Acid production from: } \\
\hline Glucose & + & + & w & w & - \\
\hline Glycerol & - & w & - & - & - \\
\hline Rhamnose & + & + & - & - & + \\
\hline Salicin & + & - & - & - & - \\
\hline \multicolumn{6}{|l|}{ Assimilation of: } \\
\hline Acetate & w & + & $\mathrm{w}$ & - & - \\
\hline $\mathrm{N}$-acetylglucosamine & $\mathrm{w}$ & + & + & + & + \\
\hline Adipate & - & - & - & - & + \\
\hline Adonitol & - & - & - & - & - \\
\hline Arabinose & + & + & + & $\mathrm{w}$ & w \\
\hline Caprate & - & + & - & - & - \\
\hline Cellobiose & + & + & + & - & + \\
\hline Citrate & - & + & - & - & - \\
\hline Fructose & + & w & + & - & w \\
\hline Fumarate & - & + & + & - & + \\
\hline Galactose & + & + & + & - & + \\
\hline Gluconate & + & + & + & - & + \\
\hline Glucose & + & + & + & w & + \\
\hline Glycerol & $\mathrm{w}$ & + & - & - & - \\
\hline Inositol & - & - & - & - & - \\
\hline Lactate & w & + & - & - & - \\
\hline Lactose & + & + & + & w & + \\
\hline Malate & - & + & w & - & - \\
\hline Malonate & - & - & - & - & - \\
\hline Maltose & + & + & + & + & + \\
\hline Mannitol & - & - & - & - & - \\
\hline Mannose & + & w & + & w & + \\
\hline Melezitose & - & $\mathrm{w}$ & - & - & - \\
\hline Melibiose & w & + & w & w & + \\
\hline$\alpha$-Methylglucoside & - & + & - & - & + \\
\hline Oxalate & - & - & - & - & - \\
\hline Propionate & $\mathrm{w}$ & + & - & - & - \\
\hline Raffinose & + & + & - & - & + \\
\hline Rhamnose & + & + & + & + & + \\
\hline Salicin & + & + & + & - & + \\
\hline Sorbitol & - & - & - & - & - \\
\hline Starch & - & $\mathrm{w}$ & w & - & $\mathrm{w}$ \\
\hline Sucrose & + & + & + & - & + \\
\hline Tartrate & - & - & - & - & - \\
\hline Trehalose & + & + & + & - & + \\
\hline Xylose & + & + & + & + & + \\
\hline
\end{tabular}

${ }^{a}+$, positive; w, weakly positive; - , negative.

isolates $\mathrm{Y}-250^{\mathrm{T}}$ and $\mathrm{Y}-345^{\mathrm{T}}$ heptadecenoic acids (17:1) were present instead of $16: 1$ fatty acid. On the other hand, the major 2-hydroxy fatty acid was 2-hydroxymyristic acid (2-OH 14:0) in the five $[A$. rhizogenes $]$ and $[C$. lividum $]$ strains. Four of the other five isolates, $\mathrm{Y}-250^{\mathrm{T}}, \mathrm{Y}-347^{\mathrm{T}}, \mathrm{Y}-348$, and $\mathrm{Y}-351$, contained 2-hydroxypentadecanoic acid (2-OH 15:0) in addition to the major components $2-\mathrm{OH} 14: 0$, and isolate $\mathrm{Y}-345^{\mathrm{T}}$ contained 2-OH 15:0 as a major component. No strain contained 3-hydroxy fatty acids. The major component of polyamine was spermidine in the three $[A$. rhizogenes $]$ strains, the two $[C$. lividum] strains, and $\mathrm{Y}-345^{\mathrm{T}}$ and homospermidine in the other isolates.

DNA-DNA homology. As shown in Table 5, the levels of DNA-DNA homology among the three $[A$. rhizogenes $]$ strains and between the two $[C$. lividum] strains were 92 to 100 and 86 to $100 \%$, respectively. The levels of homology between the three $[A$. rhizogenes] strains and all of the other strains tested (Table 5) were less than $28 \%$. The levels of homology between the two $[C$. lividum] strains and $S$. yanoikuyae were 62 and $68 \%$. Isolates $\mathrm{Y}-347^{\mathrm{T}}, \mathrm{Y}-348$, and $\mathrm{Y}-351$ exhibited high levels of 
TABLE 3. Chemotaxonomic characteristics of 3-ketolactose-producing strains

\begin{tabular}{|c|c|c|c|c|c|c|c|c|}
\hline \multirow{2}{*}{ Species or isolate } & \multirow{2}{*}{ IFO no. } & \multirow{2}{*}{$\begin{array}{c}\mathrm{G}+\mathrm{C} \\
\text { content } \\
(\text { mol\%) }\end{array}$} & \multirow{2}{*}{$\begin{array}{l}\text { Isoprenoid } \\
\text { quinone }\end{array}$} & \multirow{2}{*}{ Sphingolipid } & \multicolumn{4}{|c|}{$\begin{array}{c}\text { Polyamine content }{ }^{a} \\
(\mu \mathrm{mol} / \mathrm{g} \text { [wet } \mathrm{wt} \text { ] of cells) }\end{array}$} \\
\hline & & & & & put & spd & hspd & agm \\
\hline [Agrobacterium rhizogenes] & $15208^{\mathrm{T}}$ & 64.7 & $\mathrm{Q}-10$ & + & 0 & 1.30 & 0 & 0 \\
\hline [Agrobacterium rhizogenes] & 15209 & 65.0 & Q-10 & + & 0 & 1.70 & 0 & 0 \\
\hline [Agrobacterium rhizogenes] & 15210 & 64.9 & $\mathrm{Q}-10$ & + & 0 & 0.65 & 0 & 0 \\
\hline [Chromobacterium lividum] & 15163 & 64.0 & Q-10 & + & 0 & 1.45 & 0 & 0.01 \\
\hline [Chromobacterium lividum] & 15164 & 64.9 & $\mathrm{Q}-10$ & + & 0 & 2.05 & 0 & 0.03 \\
\hline $\mathrm{Y}-250^{\mathrm{T}}$ & $15498^{\mathrm{T}}$ & 65.4 & Q-10 & + & 0 & 0 & 1.42 & 0 \\
\hline $\mathrm{Y}-345^{\mathrm{T}}$ & $15499^{\mathrm{T}}$ & 64.8 & $\mathrm{Q}-10$ & + & 0 & 0.61 & 0 & 0.02 \\
\hline$Y-347^{\mathrm{T}}$ & $15500^{\mathrm{T}}$ & 65.9 & $\mathrm{Q}-10$ & + & 0 & 0 & 0.75 & 0 \\
\hline Y-348 & 15501 & 65.4 & $\mathrm{Q}-10$ & + & 0 & 0 & 0.57 & 0 \\
\hline Y-351 & 15502 & 65.7 & $\mathrm{Q}-10$ & + & 0 & 0 & 0.56 & 0 \\
\hline Sphingomonas paucimobilis & $13935^{\mathrm{T}}$ & $63.7^{b}$ & $\mathrm{Q}-10^{b}$ & + & 0 & 0 & 2.55 & 0 \\
\hline Sphingomonas parapaucimobilis & $15100^{\mathrm{T}}$ & $65.1^{b}$ & Q-10 & + & 0 & 0 & 2.35 & 0 \\
\hline Sphingomonas yanoikuyae & $15102^{\mathrm{T}}$ & $61.6^{b}$ & $\mathrm{Q}-10^{b}$ & + & 0 & 1.57 & 0 & 0.03 \\
\hline Sphingomonas adhaesiva & $15099^{\mathrm{T}}$ & $67.8^{b}$ & $\mathrm{Q}-10^{b}$ & + & 0 & 1.90 & 0 & 0.01 \\
\hline Sphingomonas capsulata & $12533^{\mathrm{T}}$ & $63.8^{b}$ & $\mathrm{Q}-10^{b}$ & + & 0.10 & 1.80 & 0 & 0.10 \\
\hline Sphingomonas sanguis & $13937^{\mathrm{T}}$ & $61.8^{b}$ & $\mathrm{Q}-10^{b}$ & + & 0 & 0 & 1.97 & 0 \\
\hline Sphingomonas macrogoltabidus & $15033^{\mathrm{T}}$ & $63.9^{b}$ & $\mathrm{Q}-10^{b}$ & + & 0.02 & 2.10 & 0 & 0 \\
\hline Sphingomonas terrae & $15098^{\mathrm{T}}$ & $63.0^{b}$ & $\mathrm{Q}-10^{b}$ & + & 0.02 & 2.24 & 0 & 0.01 \\
\hline Rhizomonas suberifaciens & $15211^{\mathrm{T}}$ & $59.0^{c}$ & $\mathrm{Q}-10^{c}$ & + & 0.01 & 0.58 & 0 & 0 \\
\hline Rhizomonas suberifaciens & 15212 & $58.7^{c}$ & $\mathrm{Q}-10^{c}$ & + & 0.01 & 1.25 & 0 & 0 \\
\hline
\end{tabular}

${ }^{a}$ put, putrescine; spd, spermidine; hspd, homospermidine; agm, agmatine.

$b$ Data from reference 20 .

${ }^{c}$ Data from reference 21.

homology (98 to $121 \%$ ) with each other, but lower levels of homology with $\mathrm{Y}-250^{\mathrm{T}}(24$ to $65 \%)$ and $\mathrm{Y}-345^{\mathrm{T}}$ (57 to $\left.61 \%\right)$. Similarly, the levels of homology between $\mathrm{Y}-250^{\mathrm{T}}$ and the other four new isolates and the levels of homology between $\mathrm{Y}-345^{\mathrm{T}}$ and the other four new isolates were around $60 \%$. The levels of homology between the five new isolates and the reference strains (three [A. rhizogenes] strains, one [C. lividum] strain, eight Sphingomonas strains, and one Rhizomonas suberifaciens strain) were less than $36 \%$.

Phylogenetic analysis. The sequences of 1372- and 1369nucleotide fragments of the $16 \mathrm{~S}$ rDNAs of [A. rhizogenes] IFO 15208 and [C. lividum] IFO 15163, respectively, were determined, and the primary structures were aligned and compared with each other and with the primary structures of 12 reference strains, including strains of Sphingomonas species, Erythrobacter longus (18), Rhizomonas suberifaciens, Porphyrobacter neustonensis (5), and Roseobacter denitrificans (17), which are members of the alpha subdivision of the Proteobacteria $(19,21$, 25). Calculations of levels of sequence similarity were based on the data for 1,244 nucleotides because of deletions. A phylogenetic tree based on $K_{\text {nuc }}$ values is shown in Fig. 1. As shown in Table 6 , the levels of similarity between $[A$. rhizogenes] and [C. lividum], Rhizomonas suberifaciens, and eight strains of Sphingomonas species ranged from $92.8 \%$ (S. capsulata) to $95.6 \%$ (Rhizomonas suberifaciens), while the levels of similarity between [C. lividum] and [A. rhizogenes], Rhizomonas suberifaciens, and eight strains of Sphingomonas species ranged from $91.5 \%$ (S. capsulata) to $99.4 \%$ (S. yanoikuyae).

For agrobacterium-like isolates $\mathrm{Y}-250^{\mathrm{T}}, \mathrm{Y}-345^{\mathrm{T}}$, and $\mathrm{Y}-347^{\mathrm{T}}$, partial sequences consisting of a 604-bp 16S rDNA fragment extending from nucleotides 227 to 501,720 to 894 , and 1180 to 1383 (E. coli numbering) were determined, and similarity values were calculated on the basis of this $604-\mathrm{bp}$ sequence (Table 7). The levels of similarity between $\mathrm{Y}-250^{\mathrm{T}}$

TABLE 4. Cellular fatty acid contents of 3-ketolactose-producing strains ${ }^{a}$

\begin{tabular}{|c|c|c|c|c|c|c|c|c|c|c|c|c|}
\hline \multirow{3}{*}{ Species or isolate } & \multirow{3}{*}{ IFO no. } & \multicolumn{11}{|c|}{ Fatty acid content (\%) } \\
\hline & & \multicolumn{8}{|c|}{ Nonpolar fatty acids ${ }^{b}$} & \multicolumn{3}{|c|}{ 2-OH fatty acids ${ }^{c}$} \\
\hline & & $14: 1$ & 15:0 & $16: 0$ & $16: 1$ & $17: 0$ & 17:1 & 18:0 & $18: 1$ & $14: 0$ & $15: 0$ & $16: 0$ \\
\hline [Agrobacterium rhizogenes] & $15208^{\mathrm{T}}$ & 5 & & 15 & 26 & & 2 & & 50 & 100 & $\operatorname{tr}$ & \\
\hline [Agrobacterium rhizogenes] & 15209 & 7 & & 15 & 32 & & 3 & & 43 & 100 & $\operatorname{tr}$ & \\
\hline [Agrobacterium rhizogenes] & 15210 & 4 & & 16 & 27 & & 2 & & 51 & 100 & $\operatorname{tr}$ & \\
\hline [Chromobacterium lividum] & 15163 & & & 12 & 12 & & 1 & & 76 & 94 & $\operatorname{tr}$ & 6 \\
\hline [Chromobacterium lividum] & 15164 & & & 10 & 11 & & 1 & & 70 & 93 & & 7 \\
\hline $\mathrm{Y}-250^{\mathrm{T}}$ & $15498^{\mathrm{T}}$ & & 4 & 10 & $\operatorname{tr}$ & 4 & 17 & $\operatorname{tr}$ & 68 & 47 & 45 & 8 \\
\hline $\mathrm{Y}-345^{\mathrm{T}}$ & $15499^{\mathrm{T}}$ & & 4 & 8 & $\operatorname{tr}$ & 9 & 29 & $\operatorname{tr}$ & 51 & 34 & 66 & \\
\hline $\mathrm{Y}-347^{\mathrm{T}}$ & $15500^{\mathrm{T}}$ & $\mathrm{tr}$ & & 11 & 1 & & 4 & 2 & 82 & 82 & 13 & 5 \\
\hline Y-348 & 15501 & $\operatorname{tr}$ & & 16 & 1 & & 4 & 1 & 79 & 78 & 14 & 8 \\
\hline Y-351 & 15502 & $\operatorname{tr}$ & & 11 & 1 & & 4 & 1 & 83 & 78 & 15 & 7 \\
\hline
\end{tabular}

${ }^{a}$ None of the organisms contained $3-\mathrm{OH}$ fatty acids.

${ }^{b}$ Percentage of total nonpolar acids.

$c$ Percentage of total 2-hydroxy acids. 
TABLE 5. Levels of DNA-DNA homology for Sphingomonas strains

\begin{tabular}{|c|c|c|c|c|c|c|c|c|c|c|c|c|c|c|}
\hline \multirow{3}{*}{ Species or isolate } & \multirow{3}{*}{ IFO no. } & \multirow{3}{*}{$\begin{array}{c}\mathrm{G}+\mathrm{C} \\
\text { content } \\
\text { (mol\%) }\end{array}$} & \multicolumn{12}{|c|}{$\%$ Homology with labeled DNA from: } \\
\hline & & & \multicolumn{3}{|c|}{$\begin{array}{c}\text { [A. rhizogenes }] \\
\text { strains }\end{array}$} & \multicolumn{2}{|c|}{$\begin{array}{c}\text { [C. lividum }] \\
\text { strains }\end{array}$} & \multirow{2}{*}{$\begin{array}{l}\text { S. yanoikuyae } \\
\text { IFO } 15102^{\mathrm{T}}\end{array}$} & \multirow{2}{*}{$\begin{array}{l}\text { Strain } \\
\mathrm{Y}-250^{\mathrm{T}}\end{array}$} & \multirow{2}{*}{$\begin{array}{c}\text { Strain } \\
\mathrm{Y}^{-345^{\top}}\end{array}$} & \multirow{2}{*}{$\begin{array}{c}\text { Strain } \\
\mathrm{Y}-347^{\mathrm{T}}\end{array}$} & \multirow{2}{*}{$\begin{array}{l}\text { Strain } \\
\text { Y-348 }\end{array}$} & \multirow{2}{*}{$\begin{array}{l}\text { Strain } \\
\text { Y-351 }\end{array}$} & \multirow{2}{*}{$\begin{array}{l}\text { Rhizomonas } \\
\text { suberifaciens } \\
\text { IFO } 15211^{\mathrm{T}}\end{array}$} \\
\hline & & & $\begin{array}{l}\text { IFO } \\
15208^{\mathrm{T}}\end{array}$ & $\begin{array}{c}\text { IFO } \\
15209\end{array}$ & $\begin{array}{c}\text { IFO } \\
15210\end{array}$ & $\begin{array}{c}\text { IFO } \\
15163\end{array}$ & $\begin{array}{c}\text { IFO } \\
15164\end{array}$ & & & & & & & \\
\hline [Agrobacterium rhizogenes] & $15208^{\mathrm{T}}$ & 64.7 & 100 & 95 & 95 & & & & 9 & 5 & 13 & 2 & 2 & 1 \\
\hline [Agrobacterium rhizogenes] & 15209 & 65.0 & 100 & 100 & 96 & & & & 2 & 2 & 2 & 1 & 1 & \\
\hline [Chromobacterium lividum] & 15163 & 64.0 & 5 & & & 100 & 96 & 62 & 1 & 6 & 9 & & & 13 \\
\hline [Chromobacterium lividum] & 15164 & 64.9 & & & & 86 & 100 & & & & & & & 4 \\
\hline$Y-250^{T}$ & $15498^{\mathrm{T}}$ & 65.4 & 7 & 5 & 6 & 5 & 6 & & 100 & 23 & 24 & 65 & 32 & 1 \\
\hline $\mathrm{Y}-345^{\mathrm{T}}$ & $15499^{\mathrm{T}}$ & 64.8 & 11 & 1 & 1 & & & & 46 & 100 & 61 & 57 & 57 & 1 \\
\hline $\mathrm{Y}-347^{\mathrm{T}}$ & $15500^{\mathrm{T}}$ & 65.9 & 10 & 1 & 1 & & & & 39 & 40 & 100 & 98 & 98 & 1 \\
\hline$Y-348$ & 15501 & 65.4 & 4 & 1 & 1 & & & & 47 & 46 & 101 & 100 & 99 & \\
\hline Y-351 & 15502 & 65.7 & 5 & 1 & 2 & 3 & 4 & & 61 & 63 & 121 & 104 & 100 & \\
\hline Sphingomonas paucimobilis & $13935^{\mathrm{T}}$ & 63.7 & 19 & 1 & 7 & 9 & 10 & 7 & 5 & 21 & 16 & 3 & 5 & 8 \\
\hline Sphingomonas yanoikuyae & $15102^{\mathrm{T}}$ & 61.6 & 14 & & & 68 & & 100 & 12 & 20 & 28 & & & 18 \\
\hline Sphingomonas adhaesiva & $15099^{\mathrm{T}}$ & 67.8 & 28 & & & 6 & & 9 & 26 & 26 & 22 & & & 5 \\
\hline Sphingomonas capsulata & $12533^{\mathrm{T}}$ & 63.8 & 8 & & & 8 & & 7 & 20 & 21 & 20 & & & 33 \\
\hline Sphingomonas sanguis & $13937^{\mathrm{T}}$ & 61.8 & 12 & & & 10 & & 6 & 7 & 1 & 11 & & & 2 \\
\hline Sphingomonas macrogoltabidus & $15033^{\mathrm{T}}$ & 63.9 & 1 & & & 7 & & 12 & 11 & 5 & 36 & & & 1 \\
\hline Sphingomonas terrae & $15098^{\mathrm{T}}$ & 63.0 & 13 & & & 8 & & 9 & 1 & 1 & 18 & & & 3 \\
\hline Rhizomonas suberifaciens & $15211^{\mathrm{T}}$ & 59.0 & 11 & & & 6 & 7 & & 4 & 13 & 13 & & & 100 \\
\hline Rhizomonas suberifaciens & 15212 & 58.7 & & & & 5 & 13 & & & & & & & 83 \\
\hline
\end{tabular}

and members of 11 other species, including 8 species of the genus Sphingomonas, Rhizomonas suberifaciens, $[A$. rhizogenes], and [C. lividum], ranged from $95.7 \%$ (S. capsulata) to $100 \%$ (isolate $\mathrm{Y}-347^{\mathrm{T}}$ ).

Our 16S rRNA sequence comparison confirmed that $[A$. rhizogenes], [C. lividum], and isolates $\mathrm{Y}-250^{\mathrm{T}}, \mathrm{Y}-345^{\mathrm{T}}$, and $\mathrm{Y}-347^{\mathrm{T}}$ all belong to the genus Sphingomonas.

As mentioned above, chemotaxonomic and physiological characteristics and phylogenic data showed that all of the strains which we studied are members of the genus Sphingomonas.

\section{DISCUSSION}

On the basis of chemotaxonomic and physiological characteristics and the results of DNA-DNA hybridization studies and a 16S rDNA sequence comparison, we propose the following four new species of the genus Sphingomonas: Sphingomonas rosa (type strain, IFO 15208) for the strains isolated from rose plants and formerly named [A. rhizogenes]; Sphingomonas pruni (type strain, IFO 15498) for the strains isolated from Prunus persica; and Sphingomonas asaccharolytica (type strain, IFO 15499) and Sphingomonas mali (type strain, IFO 15500 ) for the isolates obtained from apple trees. Two strains which were isolated from Psychotria nairobiensis and formerly named [C. lividum] were identified as $S$. yanoikuyae strains. $S$. rosa was isolated from the hairy roots of rose plants, but it did not contain either $\mathrm{Ti}$ or $\mathrm{Ri}$ plasmids and did not exhibit plant pathogenicity (data not shown).

Recently, on the basis of $16 \mathrm{~S}$ rRNA genes sequencing data, it was found that all of the species belonging to the genera Sphingomonas and Rhizomonas are phylogenetically related and can be divided into several subgroups $(13,24)$, although it is not appropriate at the present time to transfer these species to other genera, because they have similar chemotaxonomic characteristics and there are no remarkable morphological and physiological differences which distinguish these species at the generic level. We also suggest that the genus Sphingomonas sensu stricto should be restricted to the species $S$. paucimobilis, $S$. parapaucimobilis and $S$. sanguis and that four other species (but not $S$. capsulata), S. macrogoltabidus, $S$. terrae, $S$.

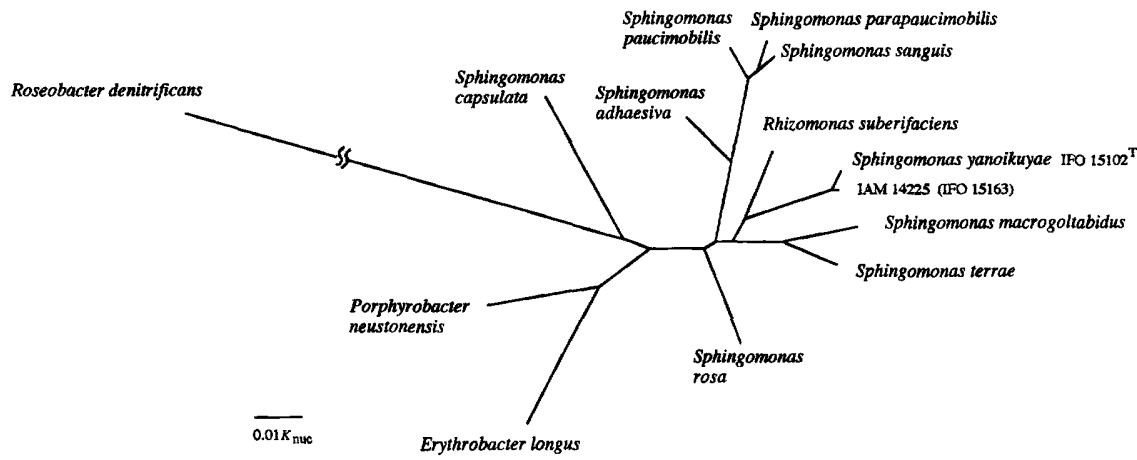

FIG. 1. Unrooted phylogenetic tree showing the relationships of Sphingomonas species. Bar $=0.01 K_{\text {nuc }}$ unit. 
TABLE 6. Levels of nucleotide similarity for 16S rDNA sequences of Sphingomonas species and other members of the alpha-4 subgroup of the Proteobacteria ${ }^{a}$

\begin{tabular}{|c|c|c|c|c|c|c|c|c|c|c|c|c|c|}
\hline \multirow[b]{2}{*}{ Species } & \multicolumn{13}{|c|}{$\%$ Similarity } \\
\hline & 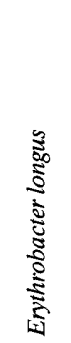 & 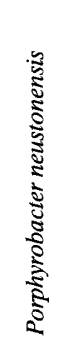 & 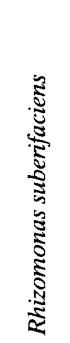 & 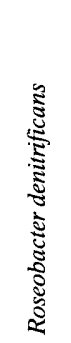 & 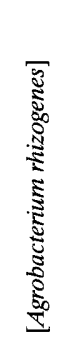 & 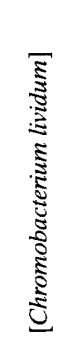 & 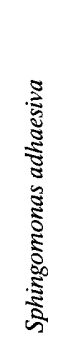 & 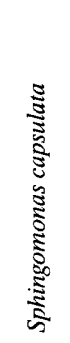 & 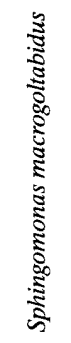 & 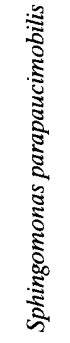 & 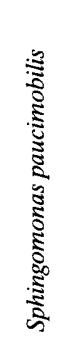 & 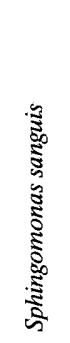 & 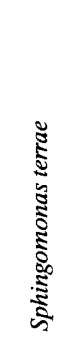 \\
\hline Porphyrobacter neustonensis & 94.2 & & & & & & & & & & & & \\
\hline Rhizomonas suberifaciens & 90.3 & 91.5 & & & & & & & & & & & \\
\hline Roseobacter denitrificans & 83.5 & 83.3 & 82.4 & & & & & & & & & & \\
\hline [Agrobacterium rhizogenes] & 91.6 & 92.7 & 95.6 & 83.0 & & & & & & & & & \\
\hline [Chromobacterium lividum] & 90.7 & 91.8 & 96.1 & 82.7 & 94.6 & & & & & & & & \\
\hline Sphingomonas adhaesiva & 91.2 & 92.2 & 94.7 & 82.6 & 94.5 & 94.7 & & & & & & & \\
\hline Sphingomonas capsulata & 90.3 & 91.2 & 91.6 & 85.1 & 93.7 & 91.5 & 91.2 & & & & & & \\
\hline Sphingomonas macrogoltabidus & 91.8 & 92.7 & 95.4 & 82.3 & 94.7 & 94.1 & 93.3 & 92.1 & & & & & \\
\hline Sphingomonas parapaucimobilis & 89.7 & 90.8 & 92.8 & 82.2 & 92.5 & 93.2 & 95.8 & 89.7 & 92.2 & & & & \\
\hline Sphingomonas paucimobilis & 90.3 & 91.2 & 92.8 & 82.3 & 92.8 & 93.1 & 95.8 & 89.6 & 92.4 & 98.6 & & & \\
\hline Sphingomonas sanguis & 90.0 & 90.8 & 93.0 & 82.0 & 92.8 & 93.2 & 96.3 & 89.9 & 92.5 & 98.8 & 98.2 & & \\
\hline Sphingomonas terrae & 91.3 & 92.3 & 96.0 & 82.5 & 95.1 & 94.5 & 93.8 & 91.3 & 97.0 & 93.1 & 93.5 & 93.6 & \\
\hline Sphingomonas yanoikuyae & 90.4 & 91.5 & 96.0 & 82.4 & 94.1 & 99.4 & 94.2 & 91.2 & 94.1 & 92.8 & 92.8 & 92.8 & 94.5 \\
\hline
\end{tabular}

${ }^{a}$ Data for a 1,244-bp sequence.

yanoikuyae, and Rhizomonas suberifaciens, should be removed from this genus (21).

The results of our $16 \mathrm{~S}$ rDNA comparison based on 1,244 bases support the results described above and also support the finding that $S$. adhaesiva belongs to the genus Sphingomonas sensu stricto, while $S$. rosa represents a distinct line of descent. [C. lividum] strains were identified as $S$. yanoikuyae strains, although the levels of DNA-DNA hybridization between $[C$.

TABLE 7. Levels of nucleotide similarity for 16S rDNA sequences of Sphingomonas species and other members of the alpha-4 subgroup of the Proteobacteria ${ }^{a}$

\begin{tabular}{|c|c|c|c|c|c|c|c|c|c|c|c|c|c|c|c|c|}
\hline \multirow[b]{2}{*}{ Species or isolate } & \multicolumn{16}{|c|}{$\%$ Similarity } \\
\hline & 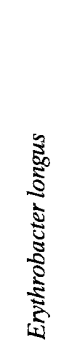 & 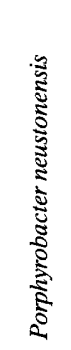 & 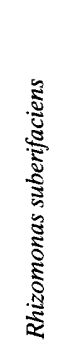 & 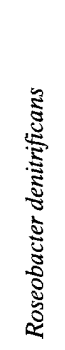 & 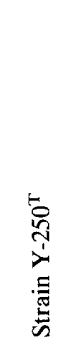 & 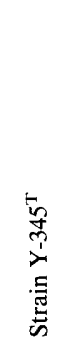 & 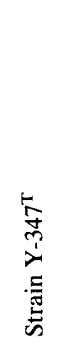 & 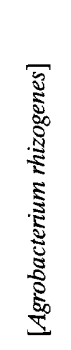 & 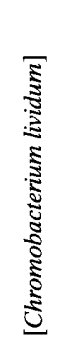 & 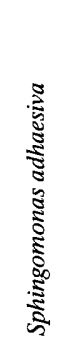 & 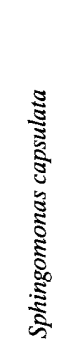 & 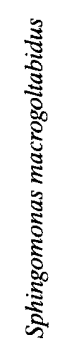 & 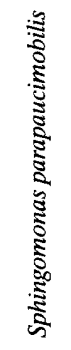 & 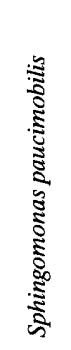 & 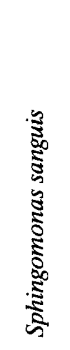 & 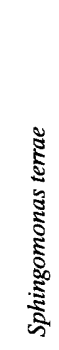 \\
\hline Porphyrobacter neustonensis & 96.5 & & & & & & & & & & & & & & & \\
\hline Rhizomonas suberifaciens & 93.2 & 94.5 & & & & & & & & & & & & & & \\
\hline Roseobacter denitrificans & 87.8 & 87.1 & 86.3 & & & & & & & & & & & & & \\
\hline $\mathrm{Y}-250^{\mathrm{T}}$ & 93.9 & 94.9 & 97.8 & 86.6 & & & & & & & & & & & & \\
\hline$Y-345^{\mathrm{T}}$ & 93.7 & 95.0 & 96.7 & 85.9 & 98.8 & & & & & & & & & & & \\
\hline $\mathrm{Y}-347^{\mathrm{T}}$ & 93.9 & 94.9 & 97.8 & 86.6 & 100 & 98.8 & & & & & & & & & & \\
\hline [Agrobacterium rhizogenes] & 94.7 & 96.4 & 96.4 & 87.1 & 97.2 & 96.0 & 97.2 & & & & & & & & & \\
\hline [Chromobacterium lividum] & 93.5 & 94.9 & 96.2 & 86.4 & 97.0 & 97.2 & 97.0 & 96.4 & & & & & & & & \\
\hline Sphingomonas adhaesiva & 94.7 & 95.0 & 96.2 & 86.8 & 97.4 & 97.8 & 97.4 & 97.4 & 97.4 & & & & & & & \\
\hline Sphingomonas capsulata & 93.9 & 95.2 & 94.9 & 86.3 & 95.7 & 94.5 & 95.8 & 97.8 & 94.9 & 95.9 & & & & & & \\
\hline Sphingomonas macrogoltabidus & 94.5 & 95.9 & 97.5 & 86.9 & 97.4 & 96.2 & 97.4 & 96.7 & 95.5 & 95.9 & 95.2 & & & & & \\
\hline Sphingomonas parapaucimobilis & 94.0 & 94.4 & 94.7 & 86.9 & 96.9 & 97.0 & 96.9 & 95.7 & 96.5 & 97.5 & 94.5 & 95.2 & & & & \\
\hline Sphingomonas paucimobilis & 94.0 & 94.7 & 95.0 & 86.9 & 97.2 & 97.4 & 97.2 & 96.0 & 96.9 & 97.7 & 94.5 & 95.5 & 99.3 & & & \\
\hline Sphingomonas sanguis & 94.4 & 94.5 & 94.9 & 86.9 & 97.0 & 97.2 & 97.0 & 96.2 & 96.4 & 98.0 & 94.7 & 95.4 & 99.5 & 99.1 & & \\
\hline Sphingomonas terrae & 94.4 & 95.8 & 97.7 & 87.3 & 98.9 & 97.7 & 98.8 & 96.9 & 94.9 & 96.7 & 95.0 & 98.0 & 96.7 & 97.0 & 96.9 & \\
\hline Sphingomonas yanoikuyae & 93.2 & 94.5 & 96.5 & 86.1 & 97.7 & 97.8 & 97.0 & 96.0 & 99.3 & 97.0 & 94.5 & 95.5 & 96.5 & 96.9 & 96.4 & 97.2 \\
\hline
\end{tabular}

${ }^{a}$ Data for a 604-bp sequence. 
TABLE 8. Differential characteristics of 13 Sphingomonas species

\begin{tabular}{|c|c|c|c|c|c|c|c|c|c|c|c|c|}
\hline Characteristic & 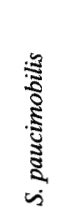 & 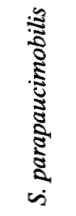 & 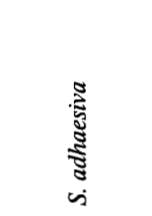 & 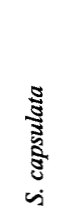 & 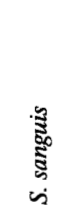 & 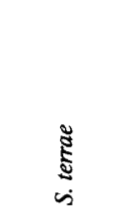 & 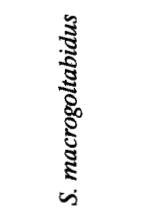 & 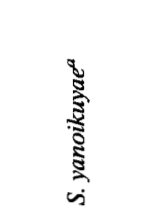 & $\frac{\grave{s}}{0}$ & $\begin{array}{l}\tilde{\Sigma} \\
\text { s. } \\
\text { is }\end{array}$ & 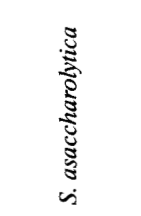 & $\begin{array}{l}\dot{\tilde{\Xi}} \\
\stackrel{\Xi}{\omega} \\
\dot{\omega}\end{array}$ \\
\hline 3-Ketolactose & $t^{b}$ & + & - & - & + & - & - & $+(+)$ & + & + & + & + \\
\hline Liquefaction of gelatin & - & + & - & - & + & - & - & $-(+)$ & - & - & - & - \\
\hline Reduction of nitrate & - & + & - & - & - & - & - & $-(+)$ & w & - & - & - \\
\hline Deamination of phenylalanine & + & - & - & + & + & - & - & $-(-)$ & + & - & - & - \\
\hline \multicolumn{13}{|l|}{ Acid produced from: } \\
\hline Glycerol & - & - & - & + & + & - & - & $-(w)$ & - & - & - & - \\
\hline Rhamnose & - & + & - & + & + & - & - & $+(+)$ & + & - & - & + \\
\hline Salicin & - & - & - & - & + & - & - & $-(-)$ & + & - & - & - \\
\hline \multicolumn{13}{|l|}{ Assimilation of: } \\
\hline Adipate & - & - & - & + & - & + & - & $-(-)$ & - & - & - & + \\
\hline Caprate & - & - & - & - & - & - & - & $+(+)$ & - & - & - & - \\
\hline Citrate & + & + & - & - & - & - & - & $+(+)$ & - & - & - & - \\
\hline Fructose & + & + & + & + & + & - & - & $+(w)$ & + & + & - & w \\
\hline Fumarate & + & + & + & + & + & + & - & $+(+)$ & - & + & - & + \\
\hline Gluconate & - & + & - & + & - & - & - & $+(+)$ & + & + & - & + \\
\hline Rhamnose & - & + & - & + & - & - & - & $+(+)$ & + & + & + & + \\
\hline Xylose & + & + & - & + & + & - & - & $+(+)$ & + & + & + & + \\
\hline Major polyamine ${ }^{c}$ & hspd & hspd & spd & spd & hspd & spd & spd & spd (spd) & spd & hspd & spd & hspd \\
\hline $\begin{array}{l}\text { Major cellular 2-hydroxy fatty } \\
\text { acid(s) }\end{array}$ & $14: 0$ & $14: 0$ & $14: 0(15: 0)$ & $14: 0$ & 14:0 & $14: 0,15: 0$ & $14: 0,16: 0$ & $14: 0(14: 0)$ & $14: 0$ & $14: 0,16: 0$ & $15: 0,14: 0$ & $14: 0(15: 0)$ \\
\hline
\end{tabular}

${ }^{a}$ The data in parentheses are data for strains IFO 15163 and IFO 15164.

${ }^{b}+$, most strains are positive; - , most strains are negative; $w$, all strains are weakly positive.

${ }^{c}$ See Table 3, footnote $a$.

lividum] and $S$. yanoikuyae strains were less than $70 \%$ (62 to $68 \%$ ). However, these strains shared many chemotaxonomic and physiological features, and the high levels of 16S rDNA similarity $(99.8 \%)$ between these two taxa support this conclusion. On the other hand, in our phylogenetic study based on a 604-bp 16S rDNA sequence, $S$. pruni and $S$. mali exhibited a high level of similarity $(100 \%)$, but these two organisms could be differentiated by DNA-DNA hybridization data and many physiological characteristics.

Differential characteristics of the new species and of previously described species of the genus Sphingomonas are shown in Table 8. S. pruni does not produce acid from rhamnose and does not assimilate adipate, $\alpha$-methylglucoside, and raffinose, but $S$. mali produces acid from rhamnose and assimilates these sugars (Table 2). These organisms also differ in their cellular fatty acid patterns (Table 4).

Strains of four of the species which we studied (S. paucimobilis, S. parapaucimobilis, $S$. sanguis, and $S$. yanoikuyae) were found to produce 3-ketolactose from lactose, as shown in Table 8. 3-Ketolactose-forming activity has been found previously only in strains belonging to Agrobacterium biovar 1, and this characteristic has proven to be a useful taxonomic marker for agrobacteria. However, in this study, we found that many species of the genus Sphingomonas contain the 3-ketolactose biosynthetic pathway. The results of a study of the distribution of 3-ketolactose-forming activity in members of the alpha subdivision of the Proteobacteria are described in the accompanying paper (15).

The new Sphingomonas species are described below.

Description of Sphingomonas rosa sp. nov. Sphingomonas rosa (ro'sa. M. L. n. rosa, rose, the source of the organism) is a gram-negative, nonsporing, motile, rod-shaped organism. Colonies are circular, entire, low convex, smooth, opaque, and whitish yellow. Indole, urease, and arginine dihydrolase are not produced. 3 -Ketolactose is produced. $\beta$-Galactosidase positive. Deamination of phenylalanine is positive. Gelatin is not liquefied. Reduction of nitrate is weak. Esculin, arabinose, cellobiose, fructose, lactose, maltose, mannose, raffinose, rhamnose, salicin, sucrose, trehalose, and xylose are assimilated, but adonitol, fumarate, malate, malonate, melezitose, sorbitol, starch, and trehalose are not assimilated. Acid is produced from glucose, rhamnose, and salicin but not from glycerol.

The $\mathrm{G}+\mathrm{C}$ content of the DNA is 64.7 to $65.0 \mathrm{~mol} \%$. The major isoprenoid quinone is Q-10. The major nonpolar fatty acids are 16:1, 18:1, and 16:0, and the major 2-hydroxy fatty acid is 2-OH 14:0. Sphingolipid is present. Source: isolated from the hairy roots of Rosa sp. (rose).

The type strain is NCPPB 2661 (= IFO 15208).

Description of Sphingomonas pruni sp. nov. Sphingomonas pruni (pru'ni. M. L. gen. n. pruni, of Prunus [Prunus persica, peach], the source of the organism) is a gram-negative, nonsporing, motile, rod-shaped organism. Colonies are circular, entire, low convex, smooth, opaque, and light yellow. $\beta$-Galactosidase positive. Indole, urease, and arginine dihydrolase are not produced. Deamination of phenylalanine is negative. $3-\mathrm{Ke}$ tolactose is produced. Reduction of nitrate is negative. Gelatin is not liquefied. Esculin, arabinose, cellobiose, fructose, fumarate, galactose, gluconate, glucose, lactose, maltose, mannose, rhamnose, salicin, sucrose, trehalose, and xylose are assimilated, but adonitol, glycerol, inositol, lactate, malonate, mannitol, raffinose, sorbitol, and tartrate are not assimilated. Acid is produced from glucose weakly, but not from glycerol, rhamnose, and salicin.

The $\mathrm{G}+\mathrm{C}$ content of the DNA is $65.4 \mathrm{~mol} \%$. The major isoprenoid quinone is Q-10. The major nonpolar fatty acids are $17: 1,18: 1,16: 0$, and the major 2-hydroxy fatty acids are $2-\mathrm{OH}$ 14:0 and 2-OH 15:0. Sphingolipid is present. Source: isolated 
from the roots of Prunus persica (peach) in Tsukuba City, Japan.

The type strain is IFO 15498 (= Y-250).

Description of Sphingomonas asaccharolytica sp. nov. Sphingomonas asaccharolytica (a.sac.cha.ro.ly'ti.ca. Gr. pref. $a$, not; Gr. n. sacchar, sugar; Gr. adj. lytica, able to loosen; M. L. adj. asaccharolytica, not digesting sugar) is a gram-negative, nonsporing, motile, rod-shaped organism. Colonies are circular, entire, low convex, smooth, opaque, and light yellow. $\beta$-Galactosidase positive. Indole, urease, and arginine dihydrolase are not produced. Deamination of phenylalanine is negative. 3-Ketolactose is produced. Reduction of nitrate is negative. Gelatin is not liquefied. Esculin, maltose, rhamnose, and xylose are assimilated, but adonitol, cellobiose, fructose, fumarate, galactose, gluconate, glycerol, inositol, lactose, malate, malonate, mannitol, raffinose, salicin, sorbitol, starch, sucrose, and trehalose are not assimilated. Acid is produced from glucose weakly, but not from glycerol, rhamnose, and salicin.

The $\mathrm{G}+\mathrm{C}$ content of the DNA is $64.8 \mathrm{~mol} \%$. The major isoprenoid quinone is Q-10. The major nonpolar fatty acids are $17: 1$ and $18: 1$, and the major 2-hydroxy fatty acids are $2-\mathrm{OH}$ 14:0 and 2-OH 15:0. Sphingolipid is present. Source: isolated from the roots of Malus spp. (apple) in Tsukuba City, Japan.

The type strain is IFO 15499 (= Y-345).

Description of Sphingomonas mali sp. nov. Sphingomonas mali (mal'i. M. L. gen. n. mali, of Malus, the apple genus, the source of the organism) is a gram-negative, nonsporing, motile, rod-shaped organism. Colonies are circular, entire, low convex, smooth, opaque, and light yellow. $\beta$-Galactosidase positive. Indole, urease, and arginine dihydrolase are not produced. Deamination of phenylalanine is negative. 3-Ketolactose is produced. Reduction of nitrate is negative. Gelatin is not liquefied. Esculin, cellobiose, fumarate, galactose, gluconate, glucose, lactose, maltose, mannose, raffinose, rhamnose, salicin, sucrose, trehalose, and xylose are assimilated, but adonitol, citrate, glycerol, inositol, lactate, malate, malonate, mannitol, sorbitol, and tartrate are not assimilated. Acid is produced from rhamnose, but not from glucose, glycerol, and salicin.

The $\mathrm{G}+\mathrm{C}$ content of the DNA is 65.4 to $65.9 \mathrm{~mol} \%$. The major isoprenoid quinone is Q-10. The major nonpolar fatty acids are 16:0 and 18:1, and the major 2-hydroxy fatty acids are 2-OH 14:0 and 2-OH 15:0. Sphingolipid is present. Source: isolated from the roots of Malus spp. (apple) in Tsukuba City, Japan.

The type strain is IFO $15500(=$ Y-351).

\section{ACKNOWLEDGMENTS}

We thank Hiroyuki Sawada, National Institute of Agroenvironmental Sciences, for the plasmid analysis and for the plant pathogenicity tests and Michio Yasuda, Fruit Tree Research Station, Ministry of Agriculture, Forestry and Fisheries of Japan, for providing bacterial strains.

\section{REFERENCES}

1. Bauwens, M., and J. De Ley. 1981. Improvements in the taxonomy of Flavobacterium by DNA:rRNA hybridization, p. $27-31$. In $\mathrm{H}$. Reichenbach and O. B. Weeks (ed.), The Flavobacterium-Cytophaga group. Verlag Chemie, Weinheim, Germany.

2. Bernaerts, M. J., and J. De Ley. 1960 . Microbiological formation and preparation of 3-ketoglucosides from disaccharides. J. Gen. Microbiol. 22:129136.

3. Bernaerts, M. J., and J. De Ley. 1963. A biochemical test for crown gall bacteria. Nature (London) 197:406-407.

4. Brosius, J., J. L. Palmer, J. P. Kennedy, and H. F. Noller. 1978. Complete nucleotide sequence of a $16 \mathrm{~S}$ ribosomal RNA gene from Escherichia coli. Proc. Natl. Acad. Sci. USA 75:4801-4805.
5. Fuerst, J. A., J. A. Hawkins, A. Holmes, L. I. Sly, C. J. Moore, and E. Stackebrandt. 1993. Porphyrobacter neustonensis gen. nov., sp. nov., an aerobic bacteriochlorophyll-synthesizing budding bacterium from fresh water. Int. J. Syst. Bacteriol. 43:125-134

6. Hamana, K., and S. Matsuzaki. 1993. Polyamine distribution patterns serve as a phenotypic marker in the chemotaxonomy of the Proteobacteria. Can. J. Microbiol. 39:304-310.

7. Hiraishi, A. 1992. Direct automated sequencing of 16S rRNA amplified by polymerase chain reaction from bacterial cultures without DNA purification. Lett. Appl. Microbiol. 15:210-213.

8. Holmes, B., and P. Roberts. 1981. The classification, identification and nomenclature of agrobacteria. Incorporating revised descriptions for each of Agrobacterium tumefaciens (Smith \& Townsent) Conn 1942, Agrobacterium rhizogenes (Riker et al.) Conn 1942, and Agrobacterium rubi (Hildebrand) Starr \& Weiss 1943. J. Appl. Bacteriol. 50:443-467.

9. Ina, Y. 1991. Molecular evolutionary analysis system from DNA and amino acid sequences (ODEN), version 1.1. DNA Data Bank of Japan, DNA Research Center, National Institute of Genetics, Mishima, Japan.

10. Kersters, K., and J. De Ley. 1984. Genus III. Agrobacterium, p. 244-254. In N. R. Krieg, and J. G. Holt (ed.), Bergey's manual of systematic bacteriology, vol. 1. The Williams \& Wilkins Co., Baltimore.

11. Kimura, M. 1980. A simple method for estimating evolutionary rates of base substitutions through comparative studies of nucleotide sequences. J. Mol. Evol. 16:111-120.

12. Mikami, H., and Y. Ishida. 1983. Post-column fluorometric detection of reducing sugars in high-performance liquid chromatography using arginine. Bunseki Kagaku 32:E207-E210.

13. Moore, E. R. B., R.-M. Wittich, P. Fortnagel, and K. N. Timmis. 1993. 16S ribosomal RNA gene sequence characterization and phylogenetic analysis of a dibenzo-p-dioxin-degrading isolate within the new genus Sphingomonas. Lett. Appl. Microbiol. 17:115-118.

14. Saitou, N., and M. Nei. 1987. The neighbor-joining method: a new method for reconstructing phylogenetic trees. Mol. Biol. Evol. 4:406-425.

15. Sakane, T., M. Takeuchi, A. De Bruyn, K. Kersters, and A. Yokota. 1995. Distribution of 3-ketolactose formation among Spingomonas spp. and other members of the alpha subclass of the Proteobacteria. Int. J. Syst. Bacteriol. 45:342-347

16. Sanger, F., S. Nicklen, and A. R. Coulson. 1977. DNA sequencing with chain-terminating inhibitors. Proc. Natl. Acad. Sci. USA 74:5463-5467.

17. Shiba, T. 1991. Roseobacter litoralis gen nov., sp. nov., and Roseobacter denitrificans sp. nov., aerobic pink-pigmented bacteria which contain bacteriochlorophyll $a$. Syst. Appl. Microbiol. 14:40-145.

18. Shiba, T., and U. Simidu. 1982. Erythrobacter longus gen. nov., sp. nov., an aerobic bacterium which contains bacteriochlorophyll $a$. Int. J. Syst. Bacteriol. 32:211-217

19. Stackebrandt, E., R. G. E. Murry, and H. G. Truper. 1988. Proteobacteria classis nov., a name for the phylogenetic taxon that includes the "purple bacteria and their relatives." Int. J. Syst. Bacteriol. 38:321-325.

20. Takeuchi, M., F. Kawai, Y. Shimada, and A. Yokota. 1993. Taxonomic study of polyethylene glycol-utilizing bacteria: emended description of the genus Sphingomonas and new descriptions of Sphingomonas macrogoltabidus sp. nov., Sphingomonas sanguis sp. nov. and Sphingomonas terrae sp. nov. Syst. Appl. Microbiol. 16:227-238.

21. Takeuchi, M., H. Sawada, H. Oyaizu, and A. Yokota. 1994. Phylogenetic evidence for Sphingomonas and Rhizomonas as nonphotosynthetic members of the alpha-4 subclass of the Proteobacteria. Int. J. Syst. Bacteriol. 44:308314.

22. Takeuchi, M., and A. Yokota. 1991. Cell-wall polysaccharides in coryneform bacteria. J. Gen. Appl. Microbiol. 35:233-252.

23. van Bruggen, A. H. C., K. N. Jochimsen, and P. Brown. 1990. Rhizomonas suberifaciens gen. nov., sp. nov., the causal agent of corky root of lettuce. Int. J. Syst. Bacteriol. 40:175-188.

24. van Bruggen, A. H. C., K. N. Jochimsen, E. M. Steinberger, P. Segers, and M. Gillis. 1993. Classification of Rhizomonas suberifaciens, an unnamed Rhizomonas species, and Sphingomonas spp. in rRNA superfamily IV. Int. J. Syst. Bacteriol. 43:1-7.

25. Woese, C. R. 1987. Bacterial evolution. Microbiol. Rev. 51:221-271.

26. Yabuuchi, E., E. Tanimura, A. Ohyama, I. Yano, and A. Yamamoto. 1979. Flavobacterium devorans ATCC 10829, a strain of Pseudomonas paucimobilis. J. Gen. Appl. Microbiol. 25:95-107.

27. Yabuuchi, E., I. Yano, H. Oyaizu, Y. Hashimoto, T. Ezaki, and H. Yamamoto. 1990. Proposals of Sphingomonas paucimobilis gen. nov. and comb. nov., Sphingomonas parapaucimobilis sp. nov., Sphingomonas yanoikuyae sp. nov., Sphingomonas adhaesiva sp. nov., Sphingomonas capsulata comb. nov., and two genospecies of the genus Sphingomonas. Microbiol. Immunol. 34:99-119.

28. Yanagi, M., and K. Yamasato. 1993. Phylogenetic analysis of the family Rhizobiaceae and related bacteria by sequencing of 16S rRNA gene using PCR and DNA sequencer. FEMS Microbiol. Lett. 107:115-120. 